\title{
Teaching has to be done differently. A few remarks about "homo zappiens" and soft communication skills of lawyers
}

\begin{abstract}
Current legal studies curricula in Poland are still "analogue", academic teachers themselves are still largely "analogue", and students and articling students live in a different world: they are "digital natives", in other words, "homo zappiens", meaning "constantly clicking". On the other hand, curricula and programmes are saturated almost exclusively with legal doctrines, but the market needs law graduates in economy, also with the knowledge of market, business and enterprise opinion principles, including special soft skills, completely different from those required for centuries in courts. The author presents arguments for the necessary reform of legal studies in connection with the above phenomena.
\end{abstract}

Keywords: homo zappiens, soft skills, reform of the legal studies curricula, new forms of communication

1 Prof. Jolanta Jabłońska-Bonca - Chief of the Department of Theory, Philosophy and History of Law, Kozminski University; e-mail: jablonska@kozminski.edu.pl 


\section{Introduction}

A new law on higher education passed by the Sejm in July 2018, ministerial concepts for the creation of university pupillage, the activity of lawyers' professional associations in connection with the discussions on pupillage models, tense situation around the Supreme Court create the state of affairs where it is worth repeating the arguments for the necessity to make qualitative changes in curricula of law studies and pupillage programmes.

The discussion about the law studies' curriculum in Poland and around the world is a permanent element of the landscape of problems bothering lawyers; it has gone on for centuries and has a huge literature. ${ }^{2}$ However, there are moments when it is of exceptional importance. This is happening now in Poland.

Lawyers understand the seriousness of the situation. Let the current discussion among solicitors serve as an illustration. An extraordinary meeting of the Polish Bar Council on pupillages and articling students was held this spring. ${ }^{3}$ Answering the editor's question: "When can we expect changes in education" Prof Maciej Gutowski, the dean of the Poznan District Bar Council, said: "They should already be in place. Time is against us. Although the Presidium tried to bring about the changes, the conservative approach prevailed". The editor asked another question: "Were you surprised?" Solicitor: "No, the Bar is conservative. Two views clash over the training. One is presented by conservatives, people personally interested in training, as well as those who choose an easier path. The other one by people willing to

2 Cf., for example, the following publications: W. Rozwadowski, O reformie studiów prawniczych w Polsce, "Edukacja Prawnicza" 1994, 1; S. Waltoś, Od dyplomu uniwersyteckiego do zawodu prawniczego, "Palestra" 1996, 3-4; Collective publication A. Turska (ed.), Humanizacja zawodów prawniczych a nauczanie akademickie, Warszawa 2002; A. Korybski, O standaryzacji nauczania na studiach prawniczych, "Państwo i Prawo" 2004, 2; J. Borkowski, Standaryzacja nauczania w naukach prawnych, "Państwo i Prawo" 2004, 2; F. Zoll, Jaka szkoła prawa?, Warszawa 2004; J. Jabłońska-Bonca, Moda na egalitaryzm w szkolnictwie wyższym i naukowa bańka spekulacyjna, "Prawo i Więź" 2013, 2; J. Morawski, Kryzys nauki prawa oraz innych nauk prawnych w Polsce i gdzie indziej, "Prawo i Więź" 2013, 2; A. Czarnota, Kryzys nauki prawa edukacja prawnicza. O niekonieczności produkowania "użytecznych idiotów", "Prawo i Więź" 2013, 3; A. Młynarska-Sobaczewska, Nuda w pałacu sprawiedliwości. O edukacji prawniczej w Polsce, "Prawo i Więź" 2013, 3; L. Rodak, M. Kiełb, Pamięciowa nauka prawa. W poszukiwaniu straconego czasu, "Prawo i Więź" 2013, 3.

3 A. Krzyżanowska, Poprawmy aplikacje - prof. M. Gutowski o konieczności zmian w ksztatceniu przyszłych adwokatów, "Rzeczpospolita" 10.03.2018, www.rp.pl/Rzecz-o-prawie/poprawmy-aplikację (access: 7.06.2018). 
move on with the time, looking ahead, but also understanding that only the quality of education can be used to combat crazy ideas involving university pupillage. The second view will ultimately win". "The changes may affect some financial interests" - the journalist continues. "But not those who want to and can educate. Besides, it is better to give up a bit of voluntarism in education than to let an alternative training to be created outside the association" - answers M. Gutowski.

Nihil novi sub sole. Without delving into details, this fragment of the conversation reflects well the situation of dispute lasting for decades over the lawyer's education model.

There was also a debate on this subject already in the Second Polish Republic. The advantages and disadvantages of the general humanistic and technical specialist education of law were considered. ${ }^{5}$

Professors of juridical science were divided. For example, Antoni Peretiatkowicz opposed "the technical teaching of law" in the course of this discussion. " "Limiting the legal education only to the issues concerning applicable regulations is contrary to the essence of university education and leads to the creation of a vocational college - for clerks. A feature of such a college would be to exclude free and independent thinking".7 Peretiatkowicz argued that a lawyer educated this way would not differ much from "a solicitor's secretary or a notary's assistant", who "(...) know legal regulations by heart, often better than their patron". ${ }^{8}$ The prevalence of general education over strictly practical education makes it possible to solve difficult problems. Law departments are to ensure that graduates leave them as "lawyers - future artists in their profession, not law craftsmen". Also, S. Estreicher claimed that "(...) a good practical lawyer (...) can only be the one who can cover the whole of legal life, and not the one who only knows a certain number of positive rules and a cer-

4 The above-mentioned "crazy ideas" are, in my opinion, crushing criticism not only of the idea of the Ministry of Justice (I disagree with it, the pupillage could be modern and competitive, of course if a qualitative leap in teaching methods in higher education is made successfully), but also crushing criticism of the current quality level of law studies at many Polish universities, education methods (or rather the lack of methods) that do not give a chance to develop the basics of reliable professional skills.

5 For more see: M. Marszał, Spór o model prawnika w Drugiej Rzeczpospolitej, "Krakowskie Studia z Historii Państwa i Prawa" 2015, 8, p. 173-183 and rich inter-war literature quoted there. Quotations of professors' views from the times of the Second Polish Republic in this article come from this text. The same problem is discussed by authors after 80 years, e.g. in issue 3/2013 of "Prawo i Więzi".

6 Here I only signal the pre-war discussion to remind that this is an everlasting problem. There are many historical studies of this subject, see for instance: M. Marszal, op. cit. and rich literature quoted there.

$7 \quad$ Cf. A. Peretiakowicz. Wywiad z profesorem dr. Antonim Peretiakowiczem Rektorem Uniwersytetu Poznańskiego, "Współczesna Myśl Prawnicza” 1936, 11, p. 7.; quotation from: M. Marszał, op. cit., p. 176.

8 Ibidem. 
tain number of office ways of attending to matters". Estreicher argued that the legal profession is very humanistic, and a lawyer must not be compared to, for example, an engineer building bridges. ${ }^{9}$

Opponents of this position argued that, first and foremost, lawyer practitioners are needed. It was necessary to focus on teaching specifically the applicable law instead of general rules. The way to implement practical teaching at university law faculties was supposed to be specialisation in a specific area of law, which, as it was pointed out, would ensure perfect preparation for the legal profession chosen by the student. It was claimed that the work of a lawyer - a social technician - can be directly compared to the work of an engineer or a doctor; after all it is impossible to require them to gain exactly all the medical or technical knowledge. ${ }^{10}$ Such a view was advocated, among others, by Czesław Znamierowski. ${ }^{11}$

The third view was an attempt to combine two views. Supporters of this $r$ trend emphasised that neither the advantage of the theoretical nor of the practical aspect in legal education may be recognised because, as W. Makowski claimed, "(...) it would be a mistake to pursue any decisive one-sidedness: practical and professional or theoretical and scientific in the organisation of university studies". ${ }^{12}$ Legal studies should combine both elements and prepare both practitioners and scientists for work.

After the Second World War, for decades there was no free academic and practical discussion about legal studies and their curricula. The solutions of the communist authorities led in 1946 to the establishment of six-month law courses in Łódź, Wrocław, Gdańsk and Torun for workers and peasants with the right ideological backbone. A-Levels were not necessary. After completing the course, one became a judge or prosecutor immediately. ${ }^{13} \mathrm{~A}$ two-year Teodor Duracz Central Legal College was established in 1948 in Warsaw. ${ }^{14}$ The "militant communists" appointed by the Central Committee of the Polish United Workers' Party, trade unions and social organisations, necessarily deprived of "bourgeois ballast" were referred to this college. Also here, there was no requirement to have A-Levels. Graduates of the Duracz College immediately became judges and prosecutors.

\footnotetext{
9 S. Estreicher, Nauczanie prawa publicznego na uniwersytetach polskich i reformy pożądane, Poznań 1936, quotation from: M. Marszal, op. cit., p. 178, see there for more.

10 J. Ordoniec, Dyletantyzm czy specjalizacja?, “Współczesna Myśl Prawnicza” 1937, 1, p. 12; C. Znamierowski, Młodzież prawnicza II, “Gazeta Polska”, 27.08.1937, p. 3.

11 Although earlier he was closer to the first view. Cf. M. Marszał, op. cit., p. 179.

12 W. Makowski, Uniwersyteckie studium prawnicze, Warszawa, p. 17-18, quotation from: M. Marszał, op. cit., p. 180.

13 For more see for instance: M. Marosz, Resortowe togi, Warszawa 2017, Chapter I, in particular pp. 46-62.

14 Ibidem, p. 49.
} 
At the same time, there were university law faculties in some Polish cities. There, even in the darkest Stalinist period, many prominent pre-war professors were lecturers - along with political officers - and they tried to teach, as far as possible the fundamental principles of law. The authorities, of course, influenced the curricula here as well. For example, the philosophy of law was abolished, and the rank of historical subjects was reduced. In order to marginalise the weight of some of them, the exercises for them were abolished. For example, such was the case for Roman law. Subjects such as the USSR political system and dialectical materialism, the course of the basics of Marxism-Leninism were introduced. Nevertheless, by skilfully choosing a seminar, one could write a master's thesis on the constitution of Switzerland or translate Volumina Legum (the first Polish case law collection).

After 1956, law studies curricula and pupillage programmes evolved depending on the political situation, but subsequent changes were not very radical. Sometimes ideological and social subjects were more numerous, sometimes less, depending on the political situation. Education methods did not change. The pupillages lasted 2-3 years. What was de facto lectured to a large extent depended on the talent, courage, personality and character of a particular professor. After 1989, the pre-war discussion about the lawyers' education profile started again with new strength, but it did not bring great qualitative changes. ${ }^{15}$ Changes in curricula were made generally by the concepts of various ministers, by joining the European Union, however - using the Gutowski's term - they meant "powdering" rather than a serious plastic surgery. ${ }^{16}$ There was no qualitative leap. ${ }^{17}$

The more serious changes (including the opening of studies for all high school graduates) - unfortunately also involving a lot of very negative effects - were brought by the years after Poland's accession to the European Union. In order to raise the enrolment rate and reach the Western Europe enrolment rate, and at the same time, in the absence of financial resources for university development, while striving to open the studies for all those willing to study, high quality was given up in favour of a high number of students at law departments. Factory halls, gyms and events halls were filled by law students. Today, graduates of the classes of those years are a generation of the most influential lawyers - fortyyearolds.

15 Numerous works, studies, etc. have been created on this subject. Cf. Footnote 2.

16 However, student legal counselling, moot courts, Socrates exchange programmes, foreign law colleges - these are examples of successful transformations.

17 Cf. J. Jabłońska-Bonca, Retoryka na studiach prawniczych w Polsce w "kleszczach encyklopedyzmu” $i$ walki o zasady dostępu do zawodów prawniczych, [in:] B. Sobczak i H. Zgółkowa (eds.), Dydaktyka retoryki, Poznań 2011. 
A new period of attempts to reform higher education begins in $2018 .^{18}$ Its new main goal is to gain recognition of Polish scientific results in the world and the scientific excellence. What will this reform bring to universities in general, and law studies in particular? I share the opinions of Wojciech Cyrul and Jerzy Stelmach expressed in the text contained in this issue of "The Critique of Law" that we are unfortunately at risk of another "unfinished reform". ${ }^{19}$

Nonetheless, one should keep trying. In this text I restrict myself only to pointing out two selected problems I consider to be important in legal education. I believe that while shaping new rules for the functioning of universities, it would also be advisable to change the curricula and methods of studying the law. Due to the principle of connected vessels, it would also entail changes in pupillage programmes. ${ }^{20}$

I would like to reuse the example of this year's discussion about the training of solicitors. "One cannot see, however, that the managers of education want serious changes - the editor claims in the cited interview in 2018 - They aim to castrate the ideas of Professor and Prof Kardas rather than to support them". ${ }^{21}$ He refers to the view of unwilling training managers: "The managers' protest negates the mechanisms of verifying the competence of lecturers and training by the Polish Bar Council, recording classes and extending the association of articling students. But it is not them who decide - says M. Gutowski - the Polish Bar Council has to consider that individual interests must not be an obstacle to proper training, and if the good proposals are castrated from the project, it will not be a reform, but powdering". ${ }^{22}$

"The idea of recording the classes did not go down well with people. And yet it is the easiest way to verify the quality of lectures." - the journalist continues.

M. Gutowski uses argumentum ad absurdum: "Maybe we will prohibit the articling students from using computers? Recording the classes is a standard in many countries. How else to create repetitive material for articling students and the same time increase the quality of classes? The protest against the idea of recording the classes is an expression of the nineteenth-century approach to education and hypocrisy". ${ }^{23}$

18 Law 2.0. "Constitution for Science".

19 I wrote about the reform implemented by Minister Kudrycka in: J. Jabłońska-Bonca, Moda na egalitaryzm...

20 The article does not contain solutions to both problems. They are being prepared as part of a research project of the Ministry of Justice. Cf. Footnote 57.

21 I.e. the ideas for a pupillage reform of the Polish Bar Council, which is not too radical, but - as rightly feared by the heads - it may reveal, among other things, low quality of classes.

22 A. Krzyżanowska, op. cit.

23 Ibidem. 
It is a fact that earlier, i.e. in February this year, "the Conference of Articling Students' Training Managers and the Law and Training Commission of Solicitor Trainees at the Polish Bar Council were in favour of maintaining the previous pupillage model, although they noticed the need to respond to the needs of articling students and the experience of the bodies during the training. They also noticed the need to constantly improve the pupillage model and to increase the attractiveness of the classes" ${ }^{24}$ The demands included e.g. the following one: "The conference recommends expanding the training offer so as to include soft skills necessary to run the office. It also recommends considering the implementation of compulsory training in mediation, culminating in a certificate entitling to an entry in the list of mediators". ${ }^{25}$

So there is some progress. However, we note that the "soft skills" training in running a law firm and mediation in Poland in 2018 is just a demand. ${ }^{26}$ However, it is impossible to reform legal studies if there is no major change in the pupillages.

Two other important aspects of soft skills, important for lawyers and their clients, and ignored in legal studies and pupillages are covered by this article.

\section{"Digital natives" or law students as "homo zappiens" versus "analogue" lecturers}

The readers most likely will agree with me that the current legal studies curricula in Poland are still "analogue", the academic teachers themselves are still largely "analogue", and students and articling students live in a different world: they are "digital natives", in other words, "homo zappiens", meaning "constantly clicking". ${ }^{27}$ Do lecturers take this fact into account when designing new didactic methods for Generation Z $?^{28}$

From a psychological point of view, an undisturbed and effective transfer of knowledge is possible if we make contact with the interlocutor, i.e. we use signs that

24 (Jaga,) Kierownicy szkolenia aplikantów adwokackich za modelem patronackim z modyfikacjami programu szkolenia, 26.02.2018, www.rp.pl/Aplikacjaadwokacka/kierownicy-szkolenia (access: 6.07.2018).

25 Ibidem

26 On 07.04.2018, the Polish Bar Council adopted a pupillage reform project in line with the concepts discussed here by M. Gutowski.

27 "Digital natives" are a generation born and raised in the world of new technologies; "homo zappiens" - a human clicking, "zapping" - continuously browsing websites. Cf. T.G. Ash, Wolne stowo. Dziesięć zasad dla połączonego świata, Kraków 2018, p. 286-288.

28 A term used in sociology meaning people born after 1990. 
mean the same to the recipient as to us. As St. Thomas Aquinas once wrote "when you want to convert a person to your view, you go over to where he is standing, take him by the hand, and guide him. You don't stand across the room and shout at him. You don't order him to come over where you are. You start where he is and work from that position. He said that's the only way to get people to budge". ${ }^{29}$ In the modern English version, the idea is expressed as follows: "If you want to teach me, you have first to reach me".

Until the end of the twentieth century, lawyers in Poland dealing in science and practice exchanged professional views mainly in their own autonomous environment, at conferences, symposia, in magazines, through professional books, jurisprudence. They required students to adapt to the style of these publications. In legal studies, the student was obliged to "go where the professor stands" and not the other way round; but now the professor "provides educational service" and is supposed to be available and communicative.

During the first year of my studies, I was studying the textbook Powszechna historia państwa i prawa by Karol Koranyi (four volumes), including footnotes and everything that was written there in fine print. It did not surprise me at all. These four volumes are 1385 pages of text. ${ }^{30}$ Later, "shorter" textbooks of common history, e.g. with only 688 pages, began to be used..$^{31}$ Students, however, are still shocked to learn from such extensive works. Even that has been reduced in some departments of law; there is currently no lecture at all in the universal history of the state and law.

As lawyers in the $20^{\text {th }}$ century agreed on their views mainly among themselves, in their communication they used almost exclusively a special professional code of communication, which Mirosława Marody calls a "developed code". ${ }^{32}$ The knowledge acquired and communicated in one's own world using the developed code is a professional knowledge with a high degree of formalisation of the learning process, it is characterised by precise methodologies that justify the inclusion of specific content into its resources, an ordered internal structure and a special conceptual apparatus. This internal structure is based on specific assumptions, linear reasoning and serial information processing. We were and are still trying to get students used to adopting a fixed list of assumptions (axiological, political, eco-

29 Quotation from: A.L. McGinnis, Sztuka motywacji, czyli jak wydobyć z ludzi to, co w nich najlepsze, Warszawa 1992, p. 33.

$30 \quad$ K. Koranyi, Powszechna historia państwa i prawa, Warszawa 1967.

31 M. Sczaniecki, K. Sójka-Zielińska, Powszechna historia państwa i prawa, Warszawa 2010.

32 For more see: M. Marody, Technologie intelektu, Warszawa 1987. The times of Stalinist pseudo-law propaganda that excluded discussion altogether are disregarded here. 
nomic ones) and to study long, linear texts. The results of reasoning, ordered knowledge appeared in this classic situation after long periods of time, thanks to systematic, individual intellectual work, provided that initial assumptions were adopted. Certainly nothing (no knowledge) was given to the reader immediately as a result of "clicking".

With the new technologies and the liberation of Polish science after 1989 from the ideology of the Polish People's Republic, jurisprudence left the traditional, hermetic world of closed scientific communication and entered the world of free thought and, to some extent, new media. It gained many channels of new opportunities for environmental dialogue and impact on public opinion and unexpectedly collided with a new type of message recipient, including students of law. Experienced lawyers and academic teachers have realised that students and articling students in version 2.0 prefer other methods of organising, processing and assimilating information.

Information (but not knowledge) on every topic is now widely available for a small price, or even for free, in particular the one on the Internet. For students, it is virtually unimportant that they do not know who its author is, how these is justified, how search engines decide which search results are shown as a priority (e.g. make up the "top ten" on the screen). It is not known why this and not the other information shows up first. The information source system is not transparent. The power over information is, in fact, in the hands of global companies - "private powers". ${ }^{33}$ "Knowledge is a public good that is often supplied by private powers" notes Timothy Garton Ash, referring, for example, to Google (now: Alphabet). ${ }^{34}$

At the same time, legal studies are formally not modern, quite commonly it is "boredom in the palace of justice". "An overwhelming sense of boredom" writes Anna Młynarska-Sobaczewska about classes at law faculties in Poland. ${ }^{35}$ "Classes (...) at the law faculty look like this: during the lecture, students are dictated to what is already written in every textbook, and the exercises involve testing and possibly explaining what was said at the lecture". ${ }^{36}$

There is no relationship between the delivered lectures and any great effort or complex intellectual technology as a result of which such a lecture was created (or rather, it should be created). If every information on the law - as students think - can be immediately "googled", so why should any professor of law have the authority? Everybody gets every single information in a second. Students are not prepared

\footnotetext{
33 As defined by T.G. Ash.

34 T.G. Ash, op. cit., p. 269.

35 A. Młynarska-Sobaczewska, op. cit., p. 64.

36 Ibidem, p. 63. This is a rule, but there are some exceptions.
} 
methodologically, they do not know the principles of ethics of scientific work, therefore they do not have the criteria that would allow them to distinguish useful knowledge from the worthless or real information from the false. Every unverified information is for them a synonym of knowledge and wisdom. In the legal sciences, such a myth of legal knowledge as cheap "commodity" that is available to everyone and can be very easily obtained has far-reaching social and political consequences (which has been manifested now with great force), much deeper than in natural or technical sciences. For instance, it blurs the specific role that the established jurisprudence should and does fulfil in the State. This is not only the role of a neutral researcher of legal phenomena.

There was an interesting hypothesis in science that a linear logical mind accustomed to many hours of focusing on a book, to the culture of Gutenbergian print, to building models of phenomena and abstract thinking is now losing its importance. A forward-looking "planner" studying every problem in a traditional way, systematically, in a linear fashion, is now "losing" with "short-sighted" "homo zappiens", who quickly gets cognitive results. ${ }^{37}$ Nicholas Carr, an American Internet researcher, in a book nominated for the Pulitzer Prize in 2011 and entitled "The Shallows: What the Internet Is Doing to Our Brains" analyses this issue, among other things, by examining the consequences of the fact that communication patterns imposed by the Internet on the person seeking now lead to constant distractions. ${ }^{38}$ Even if many statements from the Carr's popular book are only hypotheses, or justifications thereof are insufficient - it is worth taking them into account because the fact of the brain adapting to changing external stimuli (e.g. the Internet) is confirmed by numerous studies on neuroplasticity of the brain. ${ }^{39}$ Therefore, the phenomenon of "digital natives" is being examined in sociology, psychology and pedagogy. Their method of collecting, selecting and processing information is probably different because it was shaped under the influence of new information technologies. ${ }^{40}$ Students, including the students of law, have been brought up from the very birth in the presence of computers, the Internet and digital media. These have had an impact on their style of being, the way they learn, assimilate and analyse information. Computers and the Internet are for them natural elements of the world, like electricity, print or radio for the preceding generations.

37 Cf. for instance: A. Zając, Uczenie się w sieci przez zapping, "Neodidagmata" 2011, 31/32, cf. p. 109-126.

38 Polish edition: N. Carr, Płytki umyst. Jak Internet wptywa na nasze życie, Gliwice 2012.

39 See ibidem, certain rules results.

40 M. Prensky, Digital Natives, Digital Immigrants, www.marcprenscy.com/writing/Prensky. Digital Native is an analogy to a native speaker, for the former cyberspace is "homeland" (it is used by them), for the latter it is the mother tongue (a mother tongue user). 
The student's access to knowledge, 20-30 years ago was possible mainly through professorial lectures and a scientific library with paper books was formally different. In comparison with the current style of obtaining and processing information - mainly through interactive multimedia using computer and Internet technology - it results in a different approach to obtaining information, other techniques for analysing it, other ways of reasoning and another approach to scientific criticism. Is it sufficiently taken into account when designing forms of classes in legal studies?

Legal knowledge that is obtained traditionally has a sequentially organised structure. If one assimilates it, understands the principles of its systematisation and hierarchy, then - as very important for lawyers - it will be ordered in a manner similar to the one conceived and designed by the sender (legislator, court, another institution, author). This knowledge is based on the authority of a specific subject, the author. And the argument of authority has been of great importance for lawyers for centuries. ${ }^{41}$

Due to of the way and pace of information retrieval through multimedia devices and the anonymity of many texts on the Internet, the creator, sender, author of the text and the date on which the information was created are not of any major importance for "homo zappiens". It is difficult for students of law to understand the purpose of learning the names of authors of texts; these names - in the face of globalisation and multicentric sources of knowledge - do not mean anything to them. Legal studies curricula ignore the importance of the methodology of sciences, so students do not have any methodology of scientific research, they cannot independently assess the value of arguments, justifications, explanations. ${ }^{42}$ They do not understand what determines whether the knowledge obtained from a photocopy from a fellow student or from the Internet is trustworthy, they do not understand what relationship the text has with the author and why anybody would recognise anybody's authority at all. "The power of the media is so great that they affect not only how people think, but also what they think about. For many, the reality is what the media consider to be real. Everything they do not pay attention to does not seem to matter". ${ }^{43}$

41 For example, upon the order by Emperor Valentinian III, it was considered a legal principle adopted to resolve ius controversum from the works of the past that works that can be used in argumentation in a trial are only the works of five authors: Papinian, Gaius, Ulpian, Modestinus and Paulus.

42 I make hypotheses, I did not conduct systematic research, but long-term participatory observation allows me to express such judgements.

43 Quoted Instruction "Aetatis Novae" of the Pontifical Commission for Social Communications, quotation from: K. Czuba, Media i władza, Warszawa 2004, p. 92 See also: J. Jabłońska-Bonca, Prawo w kręgu mitów, Gdańsk 1996; J. Jabłońska-Bonca, K. Zeidler, Prawnik a sztuka retoryki i negocjacji, Warszawa 2016. 
Internet egalitarianism, liberalism, libertarianism and postmodernism have provided a good opportunity to adopt such an attitude. "Intellectual optimism" that is a feature thereof expresses the simple "common-sense" attitude of students to knowledge, i.e. it promotes the conviction that it is based on everyday experience, simple observation and that there is nothing in the law that would not be easily deciphered by "commonly available" means.

Linearity and careful legal reasoning according to a sequence of precise inferences, statements that perform mainly a referencing (descriptive) function, critical and creative thinking are considered to be targeted thinking. "Zapping" causes that a law student does not follow such a path in the course of reasoning, but "moves from one website to another, floats in a non-targeted and non-sequential way in a cloud of concepts and associations". Associations are free and not limited due to lacking methodology, lacking general preparation for systematising knowledge. There is no external authority organising the material. ${ }^{44}$ Associative thinking (association) makes it possible for a student to create a rather individualistic and indistinct outline of the mind map.

Knowledge (or rather a collection of information) that a reliable law student "acquires" in the Internet instead of a traditional textbook is hypertextual and has a branched structure. ${ }^{45}$ Hypertextuality was described in the scientific literature several decades ago. It consists in branching messages, which makes it possible to present them on many different planes simultaneously. Hypertext has a structure consisting of many fragments connecting with each other through numerous links. The choice and method of combining fragments depends on the decision of the message recipient, that is a law student or articling student. The recipient of information (knowledge?) is not guided on a fixed path by one author. A student in practice basically does not know who the author is at all, there are many of them, including anonymous ones. By surfing freely on the Internet, a student controls what they want to know. They are an autonomous authority. This phenomenon of recipient's empowerment has a large impact on students of various majors, but the impact on the shaping of attitudes of the students of law is exceptional, due to special assumptions of legal sciences and their practical meaning (in particular for legal doctrines regarding the rationality of the legislator).

44 Students are not interested in any of the lecturer's concepts, they do not understand why they should read their textbook, they are not interested in the concepts of their opponents, they do not understand why the knowledge from Wikipedia is not enough to pass the exam. They ask for slides from lectures; these slides, preferably pictures, form the core of knowledge.

45 The author of the concept is T. Nelsen, who developed it in the 1960s. 
An economist Richard Thaler, Nobel Prize winner with lawyer Cass Sunstein, in the book entitled: "Nudge: Improving Decisions About Health, Wealth, and Happiness" say, among other things, that the default option is a special incentive when making decisions. ${ }^{46}$ If there is no such option, there is no underlying, properly designed "architecture of choice", it is difficult for people to make the right choices in an increasingly complex world. It is easy to transfer these considerations to the description of a model situation of a law student trying to learn about creating a law, constitution or interpretation without a default option, by clicking on the Internet. ${ }^{47}$

The precision of reasoning, the basing of reasoning on principles, systematisations and order in the education and practice of lawyers were supported by persuasion using the argument of authority. Thaler and Sunstein argue that we should also note the paternalistic aspect of the "architecture of choice" because it should balance excessive liberalism. In the 1990s, the concept of "author's death" emerged, and it referred mainly to the hypertextual literature. If the recipient of the message independently "constructs" the content of the work, the author is then basically of little importance. ${ }^{48}$

I know from experience that an average law student who carefully reads a book by author $X$ about functional interpretation will end up reading with a fairly similar idea of what they have read However, if I tell a few good students to individually develop the subject: "Functional interpretation" using materials from the Internet and additionally with a recommendation to read book $X$, each of them (interested in the topic, working reliably and individually) will achieve a different cognitive result. In their work (by "clicking" on various links), they will go in different directions,

46 R. Thaler received the Nobel Prize for the use of psychological knowledge to improve the effectiveness of decision-making processes...

47 J. Polowczy, E. Marek, Czuj i decyduj, "Polityka" 2018, 27, p. 65. "Alienation of the law is a manifestation of a wider phenomenon of post-modern societies, which can be described as the expert systems becoming more and more complex. The legal profession, sharing the fate of other professions in this area, requires more and more specialisation, whereas the rules according to which a lawyer works are becoming more and more difficult to access and understand for a non-professional. This creates a problem of tension between the expansion of the law and its isolation. The evolution of the nature of law is in close connection with the alienation thereof, which consists in the shaping of the extra-textual layer of the legal order developed and kept by lawyers". P. Jabłoński, P. Kaczmarek, O trzech granicach władzy prawniczej, "Archiwum filozofii prawa i filozofii społecznej" 2013, 1, p. 94.

48 Students are not able to give the name of the author of the textbook they studied (because they learn from crib sheets, photocopies, and Wikipedia), and if I ask students migrating from another university who conducted their exam or who had classes with them, $90 \%$ of them cannot answer in the last years. They are surprised that this is important to me. I suppose it is not only the effect of the lack of interest in studying at the previous university, or even in the studies at all, but these are the "digital natives" who select information in a different way. 
freely and effortlessly moving from one piece of information to another. It will certainly be, at least in part, different information..$^{49}$

Is it necessary in this situation to change the forms and methods of education in legal studies? Or should traditional rules of professional communication of lawyers with the environment and academic teachers with students be maintained?

Academic teachers ("conservatives" within the meaning of M. Gutowski) largely rely on teaching methods from several decades ago, and the study curricula become caricature: "as in the law, so in the subject". ${ }^{50}$

Socratic dialogue in the $21^{\text {st }}$ century is, in my opinion, still a foundation of education, but it must take into account changed circumstances.

Analogue studies and digital students, seminars versus webinars, linear knowledge versus hypertextual knowledge - these are real contrasts, so how to shape modern legal studies curricula in this situation? They still require orderly knowledge based on a deep structure of reasoning, systematisation, principles. Is it necessary in the legal studies to implement gamification, webguests and webinars to attract the attention of students, and only after that to explain to them that you can also learn differently? Such methods are used in economics and management studies.

The "networked" law student wants to use "zapping" during classes, to learn visually and allegorically through images, to quickly select, associate and evaluate. A student wants a lot of methods, forms and means of education. Law teachers are not prepared for this.

In Poland, there are no didactics departments at law faculties. Why there are chemistry, mathematics or history didactics departments at universities, and there is no law and jurisprudence didactics department? It is simple, they answer the questions: because in other majors these are the departments that train future teachers to schools, colleges and universities. And the law is not taught at any of these institutions - so why would we need the methodology? This is a real paradox. Law teachers at colleges and universities do not know anything about teaching.

A student learns the law for the first time as late as at studies - not like history, chemistry or mathematics, which have been in school curricula for many years. Study of history or biology is a continuation of many years of education. Yet, a law student in Poland has never come across legal education as a pupil, and an academic teacher has no pedagogical preparation for adult education. Therefore, it is more difficult intellectually, methodologically and methodically for both sides.

49 A similar role is played by the footnotes of a printed monograph, but moving to the texts from the links requires a lot of effort.

50 Quote from: A. Młynarska-Sobaczewska, op. cit., p. 67. 


\section{Waiting for PCP}

Another important, yet ignored problem is the methodological preparation of law students and articling students for partner communication in the business world. Legal studies curricula and pupillage programmes are saturated almost exclusively with the legal doctrines, but the market needs graduates of the law in economy, also with knowledge of market, business and enterprise operation principles, including special soft skills, completely different from those required for centuries in courts. ${ }^{51}$

A vast majority of lawyers in business work with clients, are often company faces, they are responsible for development through the promotion and sale of services. That is why the knowledge about running a business and developed interpersonal skills are some of the most desirable features. And different soft skills are needed here than in court.

" $\mathrm{PCP}$ " - immediately answered the president of the board of a very large company to the question asked by me during the preparation of this article about what lawyers he needs. "PCP, i.e.: P - Proactive, C - Creative, P - Positive". Immediately after he added: conciliatory, communicative, pragmatic, able to work in a team, punctual, understanding business.

A lot of research and interviews with entrepreneurs confirm this view, but for years it has had no major impact on study curricula in Poland, where highly specialised knowledge on the content of legal solutions still reigns supreme. ${ }^{52}$

"As heads of legal departments, we should work as business people. - claims a lawyer Waldemar Koper - External lawyers work quite differently. We are supposed to speak to managers so that law is not seen. On the other hand, law firms sell their knowledge in a technical way"..$^{53}$

"Clients with whom we co-operate on a regular basis always expect us to be proactive and know the given sector. Entrepreneurs expect advice on how to attend to matters, not legal analysis. - says another lawyer Krzysztof Zakrzewski - We have to answer the question: Do we do this business or not. That is why they start reading our multi-page opinions beginning with the last page. The view of Rudolf

51 Cf. J. Jabłońska-Bonca, K. Zeidler, op. cit.

52 There are attempts to overcome these barriers; for example, the major "Management and law in business" at the Faculty of Law and Administration of the Adam Mickiewicz University in Poznan. www.prawo.uam.edu.pl/ZiPwB (access: 15.07.2018) or "Law and Finance" Kozminski University www.alk.edu.pl (access: 15.07.2018).

53 Quotation from: J. Walencik, Prawnik z korporacji musi znać się na biznesie, www.rzeczpospolita. pl (access: 03.11.2019); W. Koper, Jakich kompetencji oczekują od prawników przedsiębiorcy?, www. rzeczpospolita.pl (access: 6.01.2018). 
Ostrihansky is similar. He says that a partnering large law firm is required by clients not only to know the law well, but, first of all, to be able to give business advice, assess the risk and tell what is acceptable and what is not". ${ }^{54}$

In a legal market survey conducted in 2017, the question whether a lawyer's work in a company requires broader and more varied competences than a lawyer employed in a law firm (a court lawyer), 77 percent of surveyed heads of legal departments answered in the affirmative. The need to have an additional set of skills was emphasised by the CEOs and board members even stronger than by the directors of legal departments. First of all, they expect lawyers to understand corporate structures and business principles, and a lawyer, in addition to in-depth legal knowledge, will also gain managerial skills and will be able to talk with employees and trade partners. CEOs say that these skills are even more important than specialist knowledge. The importance of legal knowledge has not diminished - it is considered a basic and obvious competence. ${ }^{55}$

The CEOs and directors of legal departments considered competences related to communication, understanding of running a business and underlying trends most desirable.

They emphasised, for example, that the ability to speak the language of business, especially the "language of benefits" instead of merely the legal language is an important communication skill. In essence, they meant the need to teach lawyers' rhetorical and negotiating skills. "Language of benefits" is a way of conducting talks with clients, trade partners and internal stakeholders with a view to establishing a relationship that is of importance to the company. Still, is a presentation model of a legal and business solution, a product, a service involving the presentation of the "features - advantages and benefits" by a lawyer participating in the dialogue - covered by exercises during studies or pupillage?

Legal studies a favouring lectures on specific issues of the currently applicable law have many advantages, but also weaknesses. They lead to the isolation and autonomisation of codes and languages of particular legal doctrines and separation of other sciences from the results as well as practical skills and competences that a law student can and should acquire.

If a student during legal studies does not use the opportunity to learn and practise, for example, persuasion rules, business risk assessment rules or business decision-making methods, when graduating, they remain in an intellectual void

54 Views expressed by lawyers during the editorial discussion in "Rzeczpospolita" on 3.11.2009, ibidem.

55 A survey of the Polish Association of Corporate Lawyers, cf. W. Koper, op. cit. 
filled only with regulations. Yet, a lawyer works not only with regulations but, above all, with people.

Unfortunately, studies are generally focused on isolation of law students from the results of other social sciences, and the curricula promote the fragmentation of thinking about the law itself. The usefulness of the results for legal practice - in particular the skills that can be acquired through other sciences - is downplayed. Besides, limiting the theory and philosophy of law, economics and history in many law departments is explained by specific requirements resulting from pupillage exams. This method of education distracts the attention of law students in Poland from the creative and critical reflection on objectives, strategies, generalisations, tools and work techniques and does not teach holistic, systemic cultural linking of law with local and global political, economic and social phenomena. In principle, there is no discussion and no research on interdisciplinary models of legal phenomena in various non-legal contexts in co-operation with sociologists, philosophers and psychologists, and no synergy with management or economics is sought. ${ }^{56}$ Detailed legal sciences - not connected with each other and with the context - are increasingly closed language games. Everyone within a given legal doctrine solves their important specialist problems pertaining to interpretation, and language codes are closed within narrow legal specialisations.

This way, natural surrounding is created for the spread of legal myths and legal and economic stereotypes among lawyers themselves. If a lawyer does not understand the political, economic and social context, they move in an intellectual void. They have no modern and well-established knowledge of the world, but are based only on a simple examination, they fail to see many phenomena and processes and thus cannot understand them. They see a lot less because they do not have the language to describe what surrounds them. Therefore, paradoxically, they also easily succumb to illusions and the magic of common-sense thinking about law. For example, they imagine that the law is a neutral professional instrument, and business - an area where one can move efficiently without professional knowledge and skills about the principles of operation of companies and the market.

\section{Synergy of the problems of "digital natives" and the "PCP"}

Although the problems of "digital natives" and "PCP" are seemingly distant, they are actually strongly intertwined with each other and require a parallel solution in legal studies curricula.

56 Of course there are exceptions. 
First of all, globalisation of the economy causes that lawyers work more and more often in an international and online environment. International and domestic transactions are negotiated, at least partly, in the cyberspace, implemented online in seconds and organisationally do not resemble, even at the negotiation stage, business meetings conducted centuries ago, or even 30 years ago.

Are lawyers prepared during studies to negotiate in business? In the globalised Internet-based economy, the commercial logic of minimising the costs of business talks generates other circumstances of verbal and non-verbal communication than in the relations of a court lawyer attorney (solicitor or legal advisor) with clients. Lawyers preparing international and national meetings and taking part in business talks more and more often do not have to meet in person. Video conferencing, teleconferencing and increasingly difficult mixed negotiations (e.g. some are present in person in the conference room, others are present online on a computer screen or on the phone in different countries), are made more complex by the problem of choosing the language of talks, limited Internet and phone contact time for the persons negotiating the contract, create new, complex persuasive contexts. They require the use of new communication tools, including other means of persuasion than in court. Professional skills in this area have become an important competitive factor. Determining the subject of dispute, multifaceted case economisation, searching for negotiating space and concluding a settlement obliges lawyers to have a methodological preparation in this field. It is important not to delay the agreement and not generate unnecessary transaction costs, e.g. due to the attachment to the traditional court tactic "win-lose", which does not work in business. ${ }^{57}$ Working conditions and pace also generate new IT needs for lawyers in the field of search engines and databases. Therefore, the demand for skills in using new technologies increases significantly.

If the talks are conducted face to face, and legal solutions are created largely during video conferencing or teleconferencing, various elements of non-verbal communication, such as kinesics, para-language, self-presentation, proxemics and the entire situational context can be read differently than during a meeting in person. ${ }^{58}$ For example, some virtual effects that have persuasive power arise independently, they would not exist if the meeting was held in person, other are infeasible in such

57 For more see negotiation moments in the economic model in: B. Brożek, J. Stelmach, Negocjacje, Kraków 2014, s. 133; G. Stalk, Time - the Next Source of Competitive Advantage, "Harvard Business Review" 1988, 2, p. 11 et seq.

58 Kinesics - body language; para-language - tone, timbre, intensity of the voice; self-presentation - human appearance; proxemics - interpersonal distance (to people participating in the negotiations are e.g. in different countries), chronemics (event time, e.g. one person starts work, the other is after 12 hours of work on another continent), situational context (place, temperature, light). 
a situation (the screen shows only faces, you cannot see others present in the room, you do not know what they say and do, you cannot give the other side of the document, you cannot give coffee to the interlocutor, you can break the connection at any time, you can do some activities outside the screen, etc.). Others are deliberately designed in a different way, precisely because of the virtual nature of the talks, and they could also be not convincing in the real world at all. At which law departments in Poland do workshops in this area take place?

However, if we are to seek a better understanding between lawyers and business, and we recognise that partner communication is symmetrical communication, we must also agree that it requires contact, and thus a semantic community, synchronisation of signs, symbols and codes of professionals. There is also a need for contact at the level of values, at least understanding and acceptance of differences. Knowledge about people, communication with them and the mechanisms of business, politics and social life is after all a "hidden partner" of every detailed legal decision.

Therefore, on the occasion of the education reform, it would be worthwhile to make a jump, to improve the study curricula and pupillage programmes, to change some work methods so that during studies and pupillage the students are more proactive, creative, positive, conciliatory, communicative, pragmatic, able to work in teams, punctual and understand business axiology. ${ }^{59}$

59 The work carried out as part of the research curriculum of Areas I and II of the Faculty of Law at Cardinal Stefan Wyszyński University and the Ministry of Justice: "The system of training of lawyers and activities related to combating crime and assistance to victims of crime" (June-July 2018). 